\title{
ANALISIS KINERJA KEUANGAN DAERAH PEMERINTAH KOTA SALATIGA TAHUN 2014-2018
}

\author{
Endang Purwanti ${ }^{1}$, Elien Noviyanti ${ }^{2}$ \\ Dosen Program Studi Manajemen,STIE AMA Salatiga ${ }^{1}$ \\ 1) endangpurwanti@stieama.ac.id \\ Mahasiswa Program Studi Manajemen, STIE AMA Salatiga ${ }^{2}$ \\ 2) eliennov14@gmail.com
}

\begin{abstract}
ABSTRAK
Dengan diberlakukannya Otonomi Daerah dan Desentralisasi Fiskal, maka terjadi perkembangan yang signifikan dalam tata kelola kepemerintahan di Indonesia. Melalui otonomi daerah diharapkan mampu meningkatkan daya saing dengan memperhatikan prinsip demokrasi, pemerataan, keadilan, keistimewaan dan kekhususan serta potensi dan keanekaragaman daerah.Tujuan penelitian ini mengetahui Kinerja Keuangan Daerah Pemerintah Kota Salatiga. Metode Penelitian yang digunakan merupakan penelitian deskriptif kuantitatif. Teknik analisis data yang digunakan deskriptif kuantitatif Rasio Efektivitas PAD, Rasio Efisiensi Keuangan Daerah, Rasio Keserasian, Rasio Pertumbuhan, dan Rasio Kemandirian Keuangan Daerah. Hasil penelitian menunjukkan bahwa Kinerja Keuangan Daerah Kota Salatiga dilihat dari Rasio Efektivitas PAD dapat dikategorikan Tidak Efektif, karena rata-rata efektivitasnya sebesar 85,22\%, Rasio Efisiensi Keuangan Daerah tergolong Efisien karena jumlah rata-rata rasio ini sebesar 96,61\%, Rasio Keserasian dapat dikatakan bahwa Pemerintah Kota Salatiga mengalokasikan sebagian besar anggaran belanjanya untuk belanja operasi daerah yaitu rata-rata sebesar 77,88\% dibandingkan dengan rata-rata belanja modal sebesar 22,92\%, Rasio Pertumbuhan pada tahun 2018 mengalami pertumbuhan yang negatif, karena tingginya jumlah pendapatan, PAD dan belanja operasi tapi diikuti rendahnya jumlah belanja modal, Rasio Kemandirian Keuangan Daerah masih tergolong rendah dan dalam kategori pola hubungan Konsultatif karena rata-rata rasionya sebesar 27,64\%.
\end{abstract}

Kata kunci: Rasio Efisiensi, Keserasian, Pertumbuhan, dan Kemandirian

\section{PENDAHULUAN}

Dengan adanya perubahan di bidang ekonomi, sosial dan politik dalam era reformasi, yang mempunyai dampak pada percepatan perubahan perilaku masyarakat, maka mengakibatkan adanya tuntutan masyarakat akan transparansi pelaksanaan kebijaksanaan pemerintah, demokratisasi dalam pengambilan keputusan, pemberian pelayanan yang lebih berorientasi pada kepuasan masyarakat dan penerapan hukum secara konsekuen dan konsisiten dengan diberlakukannya Otonomi Daerah dan Desentralisasi Fiskal, maka terjadi perkembangan yang signifikan dalam tata kelola kepemerintahan di Indonesia. Perubahan yang terjadi antara lain dari Sistem Sentralisasi menjadi Desentralisasi, dari Sistem Anggaran Tradisional menjadi Sistem Anggaran Berbasis Kinerja, dari Sistem Akuntabilitas Vertikal menjadi Sistem Akuntabilitas Horizontal, dari Sistem Akuntansi Single Entry dan Cash Basis menjadi Sistem Akuntansi Double Entry dan Accrual Basis. Otonomi daerah tersebut diarahkan untuk mempercepat 
terwujudnya kesejahteraan masyarakat melalui peningkatan pelayanan, pemberdayaan dan peran serta masyarakat. Di samping itu melalui otonomi, daerah diharapkan mampu meningkatkan daya saing dengan memperhatikan prinsip demokrasi, pemerataan, keadilan, keistimewaan dan kekhususan serta potensi dan keanekaragaman daerah. Dalam rangka meningkatkan efisiensi dan efektivitas penyelenggaraan otonomi daerah maka otonomi ini dititikberatkan pada daerah kabupaten/kota karena daerah kabupaten/kota berhubungan langsung dengan masyarakat. Laporan keuangan sektor publik merupakan alat pengendalian dan evaluasi kinerja manajerial dan organisasi. Fungsi utama dari laporan keuangan sektor public adalah untuk memberikan informasi keuangan kepada pihak-pihak yang berkepentingan dengan laporan tersebut yang akan digunakan sebagai dasar pengambilan keputusan ekonomi, sosial, dan politik (Mardiasmo, 2002). Akan tetapi masih banyak pihak yang belum memahami atau bisa membaca laporan keuangan dengan baik. Hal tersebut wajar, karena berbagai pihak yang berkepentingan tersebut berasal dari latar belakang yang berbeda dan tidak memahami akuntansi. Dalam menganalisis suatu laporan keuangan bisa menggunakan metodemetode dan salah satunya yang paling banyak digunakan adalah analisis rasio keuangan. Rasio keuangan untuk menilai kinerja keuangan daerah meliputi, rasio kemandirian, rasio efektivitas, rasio efisiensi, rasio aktivitas dan rasio kemandirian (Rahayu, 2017). Dengan diberlakukannya otonomi daerah seharusnya pemerintah Kota Salatiga harus lebih berani dan mampu memaksimalkan berbagai potensi yang dimilikinya, maka peran masyarakat sebagai subyek dan obyek pembangunan sangat diperlukan untuk selalu memantau dan mengawasi kinerja pemerintah daerah.

Masalah dalam penelitian ini Bagaimana Kinerja Keuangan Pemerintah Kota Salatiga tahun 2014-2018. Adapun tujuan penelitian untuk mengetahui Rasio Efektifitas PAD (REPAD), Rasio Efisiensi Keuangan Daerah (REKD). Rasio Keserasian, Rasio Pertumbuhan, Rasio Kemandirian Keuangan Daerah (RKKD). Hasil penelitian ini diharapkan dapat bermanfaat bagi pemerintah daerah untuk meningkatkan akuntabilitas kinerja keuangannya.

\section{LANDASAN TEORI}

\section{Landasan Teori}

\section{Kinerja Keuangan Daerah}

Menurut (Mahsun, 2012), kinerja merupakan gambaran mengenai tingkat pencapaian pelaksanaan suatu kegiatan / program/ kebijakan dalam mewujudkan sasaran, tujuan, misi dan visi organisasi yang tertuang dalam strategic planning suatu organisasi. Menurut (Mardiasmo, 2002) Kinerja Keuangan Daerah adalah tingkat capaian dari suatu hasil kerja di bidang keuangan daerah dengan menggunakan indikator keuangan yang telah ditetapkan sebelumnya dengan tujuan untuk mengetahui kemampuan suatu daerah dalam mengelola keuangannya. Pengukuran Kinerja Pemerintah Daerah harus mencakup pengukuran Kinerja Keuangan. (Mardiasmo, 2002)

\section{Analisis Kinerja Keuangan Daerah}

Menurut Helfert (1982) dalam (Mahsun, 2012), analisis Laporan Keuangan merupakan alat yang digunakan dalam memahami masalah dan peluang yang terdapat dalam laporan keuangan.Penggunaan analisis rasio pada sektor publik khususnya terhadap APBD belum banyak dilakukan, sehingga secara teori belum ada kesepakatan 
secara bulat mengenai nama dan kiadah pengukurannya. Meskipun demikian, dalam rangka pengelolaan keuangan daerah yang transparan, jujur, demokratis, efektif, efisien, dan akuntabel, analisis rasio terhadap APBD perlu dilaksanakan meskipun kaidah pengakuntansian dalam APBD berbeda dengan laporan keuangan yang dimiliki perusahaan swasta (Halim \& Kusufi, 2007). Analisis rasio keuangan APBD dilakukan dengan membandingkan hasil yang dicapai dari satu periode dibandingkan dengan periode sebelumnya sehingga dapat diketahui bagaimana kecenderungan yang terjadi. Selain itu dapat pula dilakukan dengan cara membandingkan dengan rasio keuangan yang dimiliki suatu pemerintah daerah tertentu dengan rasio keuangan daerah lain yang terdekat ataupun yang potensi daerahnya relatif sama untuk dilihat bagaimana posisi rasio keuangan pemerintah daerah tersebut terhadap pemerintah daerah lainnya. Ada beberapa cara untuk mengukur Kinerja Keuangan Daerah salah satunya yaitu dengan menggunakan Rasio Kinerja Keuangan Daerah. rasio yang Rasio Efektivitas PAD, Rasio Efisiensi Keuangan Daerah, Rasio Keserasian, Rasio Pertumbuhan, dan Rasio Kemandirian Keuangan Daerah.

\section{Rasio Efektivitas Pendapatan Asli Daerah (REPAD)}

Rasio Efektivitas Pendapatan Asli Daerah (REPAD) menunjukkan kemampuan pemerintah daerah dalam memobilisasi penerimaan PAD sesuai dengan yang ditargetkan (Mahmudi, 2016). Untuk mengetahui REPAD dengan membandingkan Realisasi PAD dengan Anggaran PAD. Kriteria Rasio Efektivitas menurut (Mahsun, 2012), adalah :

a) Jika diperoleh nilai kurang dari 100\% $(\mathrm{x}<100 \%)$ berarti tidak efektif.

b) Jika diperoleh nilai sama dengan $100 \%(\mathrm{x}=100 \%)$ berarti efektivitas berimbang.

c) Jika diperoleh nilai lebih dari 100\% (x > 100\%) berarti efektif.

\section{Rasio Efisiensi Keuangan Daerah}

Rasio Efisiensi Keuangan Daerah (REKD) perbandingan antara besarnya biaya yang dikeluarkan untuk memperoleh pendapatan dengan realisasi pendapatan yang diterima. Kinerja Keuangan Pemerintahan Daerah dalam melakukan pemungutan pendapatan dikategorikan efisien apabila rasio yang dicapai kurang dari 1 (satu) atau di bawah $100 \%$. Semakin kecil Rasio Efisiensi Keuangan Daerah berarti Kinerja Keuangan Pemerintah Daerah semakin baik. Untuk itu pemerintah daerah perlu menghitung secara cermat berapa besar biaya yang dikeluarkan untuk merealisasikan seluruh pendapatan yang diterimanya sehingga dapat diketahui apakah kegiatan pemungutan pendapatannya tersebut efisien atau tidak. Hal itu perlu dilakukan karena meskipun pemerintah daerah berhasil merealisasikan target penerimaan pendapatan sesuai dengan target yang ditetapkan, namun keberhasilan itu kurang memiliki arti apabila ternyata biaya yang dikeluarkan untuk merealisasikan target penerimaan pendapatannya itu lebih besar daripada realisasi pendapatan yang diterimanya. (Halim \& Kusufi, 2007)

\section{Rasio Keserasian}

Rasio Keserasian menggambarkan bagaimana pemerintah daerah memprioritaskan alokasi dananya pada Belanja Rutin dan Belanja Pembangunannya secara optimal. Semakin tinggi persentase dana yang dialokasikan untuk Belanja Rutin berarti persentase Belanja investasi (Belanja Pembangunan) yang digunakan untuk menyediakan sarana dan prasarana ekonomi masyarakat cenderung semakin kecil (Halim \& Kusufi, 2007). Ada 2 perhitungan dalam Rasio Keserasian ini, yaitu : Rasio Belanja Operasi dan Rasio Belanja 
Modal. Rasio Belanja Operasi merupakan perbandingan antara total Belanja Operasi dengan Total Belanja Daerah. Rasio ini menginformasikan mengenai porsi belanja daerah yang dialokasikan untuk Belanja Operasi. Pada umumya proporsi Belanja Operasi mendominasi total belanja daerah, yaitu antara 60-90\%. Pemerintah daerah dengan tingkat pendapatan yang tinggi cenderung memiliki porsi belanja operasi yang lebih tinggi dibandingkan pemerintah daerah yang tingkat pendapatannya rendah (Mahmudi, 2016). Rasio Belanja Modal merupakan perbandingan antara total realisasi belanja modal dengan total belanja daerah. Belanja modal memberikan manfaat jangka menengah dan panjang juga bersifat rutin. Pada umumnya proporsi belanja modal dengan belanja daerah adalah antara 5-20\% (Mahmudi, 2016). Negara berkembang peranan pemerintah daerah untuk memacu pelaksanaan pembangunan masih relatif besar. Oleh karena itu, rasio belanja modal (pembangunan) yang relatif masih kecil perlu ditingkatkan sesuai dengan kebutuhan pembangunan didaerah.

\section{Rasio Pertumbuhan}

Rasio pertumbuhan bermanfaat untuk mengatahui apakah pemerintah daerah dalam tahun anggaran bersangkutan atau selama beberapa periode anggaran, kinerja anggarannya mengalami pertumbuhan pendapatan atau belanja secara positif atau negatif (Mahmudi, 2016). Rasio ini mengukur seberapa besar kemampuan pemerintah daerah dalam mempertahankan dan meningkatkan keberhasilannya yang telah dicapai dari satu periode ke periode berikutnya. Dengan diketahuinya pertumbuhan untuk masing-masing komponen sumber pendapatan dan pengeluaran, dapat digunakanuntuk mengevaluasi potensi-potensi mana yang perlu mendapatkan perhatian. (Halim \& Kusufi, 2007)

\section{Rasio Kemandirian Keuangan Daerah}

Rasio Kemandirian Keuangan Daerah (RKKD) menunjukkan tingkat kemampuan suatu daerah dalam membiayai sendiri kegiatan pemerintah, pembangunan dan pelayanan kepada masyarakat yang telah membayar pajak dan retribusi sebagai sumber pendapatan yang diperlukan daerah. Rasio Kemandirian Keuangan Daerah ditunjukkan oleh besarnya Pendapatan Asli Daerah dibandingkan dengan Pendapatan Daerah yang berasal dari sumber lain (Pendapatan Transfer) antara lain : Bagi hasil pajak, Bagi hasil bukan pajak sumber daya alam, Dana alokasi umum dan Alokasi khusus, Dana darurat dan pinjaman (Halim \& Kusufi, 2007). Semakin tinggi Rasio Kemandirian Keuangan Daerah bahwa semakin rendah tingkat ketergantungan pemerintah daerah terhadap bantuan dari pemerintah pusat dan demikian pula sebaliknya. Rasio Kemandirian Keuangan Daerah juga menggambarkan tingkat partisipasi masyarakat dalam pembangunan daerah. Semakin tinggi Rasio Kemandirian Keuangan Daerah, semakin tinggi partisipasi masyarakat dalam membayar pajak dan retribusi daerah yang merupakan komponen utama Pendapatan Asli Daerah. Semakin tinggi masyarakat membayar pajak dan retribusi daerah menggambarkan bahwa tingkat kesejahteraan masyarakat semakin tinggi. Sebagai pedoman dalam melihat pola hubungan dengan kemampuan daerah (dari sisi keuangan )

Menurut (Halim \& Kusufi, 2007) hubungan tentang pemerintah pusat dengan daerah dalam melaksanakan kebijakan otonomi daerah, yang paling utama yaitu mengenai hubungan pelaksanaan undang-undang tentang perimbangan keuangan antara pemerintah pusat dengan pemerintah, yaitu :

a) Pola hubungan instruktif, di mana peranan pemerintah pusat lebih dominan dari pada kemandirian pemerintah daerah (daerah yang tidak mampu melaksanakan otonomi daerah). 
b) Pola hubungan konsultatif, yaitu campur tangan pemerintah pusat sudah mulai berkurang karena daerah dianggap sedikit lebih mampu melaksanakan otonomi daerah.

c) Pola hubungan partisipatif, peranan pemerintah pusat sudah mulai berkurang, mengingat daerah yang bersangkutan tingkat kemandiriannya mendekati mampu melaksanakan urusan otonomi daerah.

d) Pola hubungan delegatif, yaitu campur tangan pemerintah pusat sudah tidak ada karena daerah telah benar-benar mampu dan mandiri dalam melaksanakan urusan otonomi daerah.

\section{Penelitian Terdahulu}

Penelitian dari (Pramono, 2014) Analisis Rasio Untuk Menilai Kinerja Keuangan Daerah. Penelitian ini dilakukan pada Pemerintah Kota Surakarta. Hasil penelitian Kinerja Keuangan Pemerintah Kota Surakarta sudah sangat efisien dan efektif dalam mengelola dana, dan kemampuan melunasi pinjaman masih mencukupi. Namun dikatakan masih kurang dilihat dari aspek kemandirian dan aspek keserasian.

Penelitian yang dilakukan oleh (Rahayu, 2017) Analisis Rasio Keuangan Daerah Untuk Menilai Kinerja Keuangan Daerah dengan studi kasus pada Dinas Pendapatan, Pengelolaan Keuangan dan Aset Kabupaten Trenggalek. hasil penelitian kinerja keuangan Daerah Kabupaten Trenggalek dilihat dari (a) Rasio kemandirian daerah sangat baik dalam menjalankan tugas-tugas pemerintahan, pelayanan, dan pembangunan, (b) Rasio efektivitas, dikategorikan efektif, (c) Rasio efisiensi daerah tergolong sangat efisien, (d) Rasio Keserasian dapat dikatakan bahwa Pemerintah Kabupaten Trenggalek mengalokasikan sebagian besar anggaran belanjanya untuk belanja operasi daerah ratarata yaitu sebesar 85,33 dibandingkan dengan rata-rata belanja modal sebesar 14,64\%, (e) Rasio pertumbuhan PAD, Belanja Operasi, belanja pertumbuhan, hasil rata-rata menunjukkan pertumbuhan positif yang artinya sangat baik.

Penelitian dari (Dewi, 2016) Analisis Kinerja Keuangan Pemerintah Daerah Melalui Pengelolaan Anggaran Pendapatan dan Belanja Daerah dengan studi kasus pada Pemerintah Kota Salatiga. Hasil penelitian bahwa kinerja keuangan Pemerintah Kota Salatiga jika dilihat dari rasio kemandirian keuangan masih belum cukup baik karena presentase yang dihasilkan cenderung rendah. Dilihat dari rasio aktivitas besarnya pengeluaran untuk belanja rutin (belanja operasi) cenderung lebih tinggi dibandingkan dengan belanja pembangunan (belanja modal). Rasio efektivitas pendapatan menunjukan hasil yang baik karena pengelolaannya dinilai sudah efektif. Sedangkan rasio efisiensi belanja pada jangka waktu tersebut masih belum efisien. Rasio perumbuhan PAD dan TPD pemerintah Kota Salatiga masih belum stabil.

\section{KERANGKA PEMIKIRAN}

Pemerintah Daerah yang maju dan berkembang adalah daerah yang mampu menciptakan roda pemerintahan yang transparan, akuntabilitasnya tinggi, dan penerapan value for money yang benar. Kinerja Keuangan Daerah adalah tingkat pencapaian dari suatu hasil kerja di bidang keuangan daerah yang meliputi penerimaan dan belanja daerah dengan menggunakan indikator keuangan yang ditetapkan melalui suatu kebijakan atau ketentuan perundang- undangan selama satu periode anggaran. Bentuk kinerja tersebut berupa rasio keuangan yang terbentuk dari unsur Laporan Pertanggungjawaban Kepala Daerah berupa perhitungan APBD (Halim \& Kusufi, 2012). Salah satu cara untuk menganalisis kinerja keuangan Pemerintah Daerah adalah dengan melakukan rasio 
keuangan terhadap Anggaran Pendapatan dan Belanja Daerah (APBD) yang telah ditetapkan dan dilaksanakan. Penilaian kinerja keuangan pemerintah berdasarkan rasio keuangan diantaranya Rasio Efektivitas PAD, Rasio Efisiensi Keuangan Daerah, Rasio Keserasian, Rasio Pertumbuhan, dan Rasio Kemandirian Keuangan Daerah (Halim \& Kusufi, 2012).

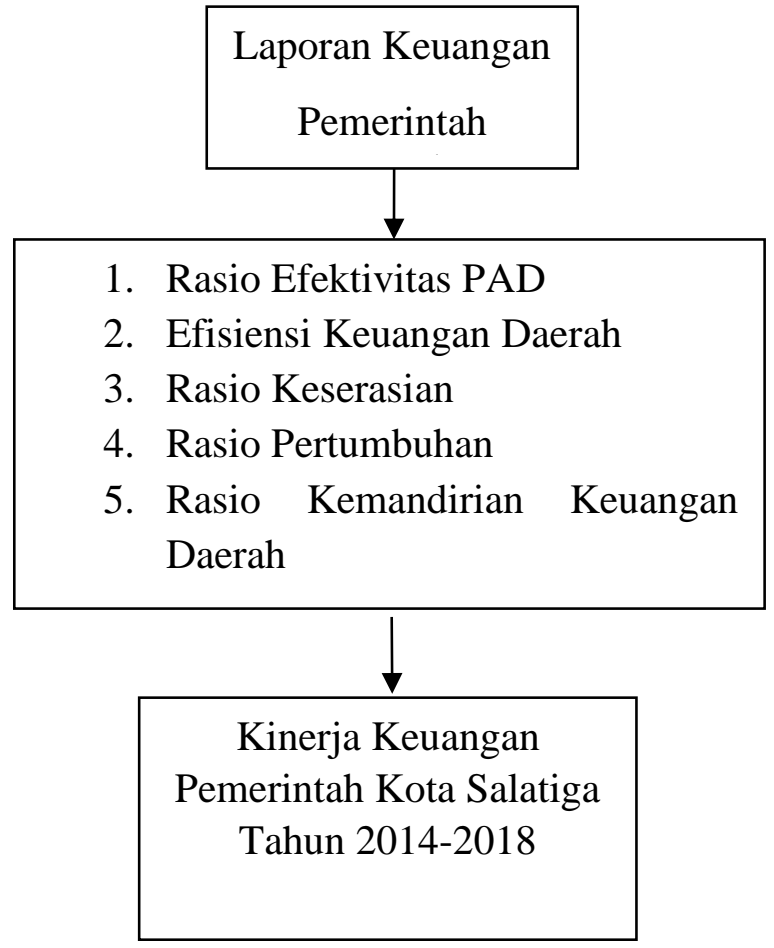

Gambar 1. Kerangka Pemikiran

Dengan menggunakan beberapa rasio diatas dapat diketahui Kinerja Keuangan Daerah Kota Salatiga. Jika semua rasio diatas menunjukkan hasil angka yang sesuai target, maka kinerja Keuangan Pemerintah Daerah Kota Salatiga dapat dikatakan baik.

\section{METODE PENELITIAN}

\section{Satuan Pengamatan dan Satuan Analisis}

(Harinaldi \& Eng, 2005) berpendapat satuan pengamatan adalah kumpulan dari keseluruhan pengukuran, objek atau individu yang sedang dikaji. Satuan pengamatan dalam penelitian ini adalah Badan Keuangan Daerah (BKD) Kota Salatiga.

(Hamidi, 2005) unit analisis adalah satuan yang diteliti yang bisa berupa individu, kelompok, benda atau suatu latar peristiwa sosial seperti misalnya aktivitas atau kelompok sebagai subjek penelitian.Satuan analisis dalam penelitian ini adalah data Laporan Realisasi Anggaran Pendapatan dan Belanja Daerah Pemerintah Kota Salatiga periode tahun 2014-2018.

\section{Metode Analisis Data}

Metode analisis dalam penelitian ini adalah metode analisis deskriptif kuantitatif (Descriptive Kuantitative Analysis Method) yaitu melakukan perhitungan-perhitungan terhadap data keuangan yang diperoleh untuk memecahkan masalah yang ada sesuai dengan tujuan penelitian (Purwanto, 2007). 


\section{Definisi Konsep dan Operasional}

\section{Rasio Efektivitas PAD}

Rasio Efektivitas PAD menunjukkan kemampuan Pemerintah Daerah dalam memobilisasi penerimaan PAD sesuai dengan yang ditargetkan (Mahmudi, 2016). Semakin tinggi Rasio efektifitas PAD, maka semakin baik kinerja pemerintah :

$$
\text { Rasio Efektivitas PAD }=\frac{\text { Realisasi PAD }}{\text { Anggaran PAD }} \times 100 \%
$$

Kriteria Rasio Efektivitas PAD menurut (Mahsun, 2012), adalah :

a) Jika diperoleh nilai kurang dari $100 \%(\mathrm{x}<100 \%)$ berarti tidak efektif.

b) Jika doperoleh nila sama dengan $100 \%(\mathrm{x}=100 \%)$ berarti efektivitas berimbang.

c) Jika diperoleh nilai lebih dari 100\% (x > 100\%) berarti efektif.

\section{Rasio Efisiensi Keuangan Daerah (REKD)}

Rasio Efisiensi Keuangan Daerah menggambarkan perbandingan antara besarnya biaya yang dikeluarkan untuk memperoleh pendapatan dengan realisasi pendapatan yang diterima. Kinerja pemerintah daerah dalam melakukan pemungutan pendapatan dikategorikan efisien apabila rasio yang dicapai kurang dari 1 atau dibawah $100 \%$. Semakin kecil rasio efisiensi berarti kinerja pemerintah semakin baik. Rumus yang digunakan dalam menghitung rasio ini adalah :

\begin{tabular}{cc|}
\hline REKD $=\frac{\text { Realisasi Belanja Daerah }}{\text { Realisasi Pendapatan Daerah }} \times 100 \%$ \\
\hline Tabel 1 : Kriteria Efisiensi Kinerja Keuangan \\
\hline Kriteria Efisiensi & Persentase Efisiensi \\
\hline $100 \%$ keatas & Tidak Efisien \\
$100 \%$ & Efisiensi Berimbang \\
Kurang dari 100\% & Efisien \\
\hline
\end{tabular}

Sumber : (Mahsun, 2012)

\section{Rasio Keserasian}

Rasio keserasian menggambarkan bagaimana pemerintah daerah memprioritaskan alokasi dananya pada belanja operasi dan belanja modal secara optimal. Ada 2 perhitungan dalam rasio kserasian ini, yaitu : Rasio Belanja Operasi dan Rasio Belanja Modal.

Rasio belanja operasi merupakan perbandingan antara total belanja operasi dengan total belanja daerah (Mahmudi, 2016). Rasio belanja operasi dirumuskan sebagai berikut

$$
\text { Rasio Belanja Operasi }=\frac{\text { Total Belanja Operasi }}{\text { Total Belanja Daerah }} \times 100 \%
$$

Rasio belanja modal merupakan perbandingan antara total realisasi belanja modal dengan total belanja daerah (Mahmudi, 2016). Rasio belanja modal dirumuskan sebagai berikut : 


$$
\text { Rasio Belanja Modal }=\frac{\text { Total Belanja Modal }}{\text { Total Belanja Daerah }} \times 100 \%
$$

Belum ada patokan yang pasti berapa besarnya rasio belanja operasi maupun modal terhadap APBD yang ideal, karena sangat dipengaruhi oleh dinamisasi kegiatan pembangunan dan besarnya kebutuhan investasi yang diperlukan untuk mencapai pertumbuhan yang ditargetkan. Namun demikian, sebagai kota di negara berkembang peranan pemerintah kota untuk memacu pelaksanan pembangunan masih relatif besar. Oleh karena itu, rasio belanja modal (pembangunan) yang relatif masih kecil perlu ditingkatkan sesuai dengan kebutuhan pembangunan di daerah.

\section{Rasio Pertumbuhan}

Rasio pertumbuhan bermanfaat untuk mngetahui apakah pemerintah daerah dalam tahun anggaran bersangkutan atau selama beberapa periode anggaran, kinerja anggarannya mengalami pertumbuhan pendapatan atau belanja secara positif atau negatif (Mahmudi, 2016). Rumus untuk menghitung rasio pertumbuhan adalah sebagai berikut :

$$
r=\frac{P n-P 0}{P 0}
$$

\section{Rasio Kemandirian Keuangan Daerah (RKKD)}

Rasio kemandirian keuangan daerah menunjukkan tingkat kemampuan suatu daerah dalam membiayai sendiri kegiatan pemerintah, pembangunan, dan pelayanan kepada masyarakat yang telah membayar pajak dan retribusi sebagai sumber pendapatan yang diperlukan daerah. Rasio kemandirian keuangan daerah ditunjukkan oleh besarnya Pendapatan Asli Daerah (PAD) dibandingankan dengan Pendapatan Daerah yang berasal dari sumber lain (pendapatan transfer) antara lain : bagi hasil pajak, bagi hasil bukan pajaksumber daya alam, dana alokasi umum dan alokasi khusus, dana darurat dan pinjaman (Halim \& Kusufi, 2007). Rumusnya adalah sebagai berikut :

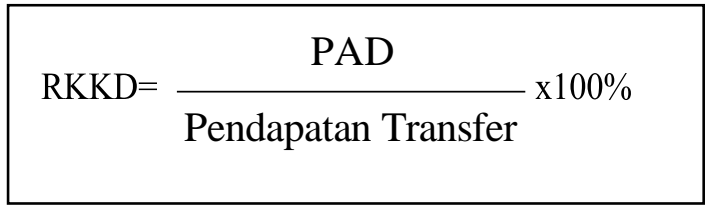

Tabel 2 : Pola Hubungan dan Tingkat Kemampuan Daerah

\begin{tabular}{ccc}
\hline Kemampuan Keuangan & Kemandirian (\%) & Pola Hubungan \\
\hline Rendah Sekali & $0 \%-25 \%$ & Instruktif \\
Rendah & $25 \%-50 \%$ & Konsultatif \\
Sedang & $50 \%-75 \%$ & Partisipatif \\
Tinggi & $75 \%-100 \%$ & Delegatif \\
\hline
\end{tabular}

Sumber : (Halim \& Kusufi, 2007)

Menurut (Halim \& Kusufi, 2007) dikemukakan hubungan tentang pemerintah pusat dengan daerah dalam melaksanakan kebijakan otonomi daerah, yang paling utama yaitu mengenai hubungan pelaksanaan undang-undang tentang perimbangan keuangan antara pemerintah pusat dengan pemerintah, yaitu : 
a) Pola hubungan instruktif, di mana peranan pemerintah pusat lebih dominan dari pada kemandirian pemerintah daerah (daerah yang tidak mampu melaksanakan otonomi daerah).

b) Pola hubungan konsultatif, yaitu campur tangan pemerintah pusat sudah mulai berkurang karena daerah dianggap sedikit lebih mampu melaksanakan otonomi daerah.

c) Pola hubungan partisipatif, peranan pemerintah pusat sudah mulai berkurang, mengingat daerah yang bersangkutan tingkat kemandiriannya mendekati mampu melaksanakan urusan otonomi daerah.

d) Pola hubungan delegatif, yaitu campur tangan pemerintah pusat sudah tidak ada karena daerah telah benar-benar mampu dan mandiri dalam melaksanakan urusan otonomi daerah.

\section{HASIL DAN PEMBAHASAN}

Hasil_dari Analisis Rasio tersebut adalah:

\section{Tabel 3 : Rasio Keuangan Daerah Pemerintah Kota Salatiga Tahun 2014-2018}

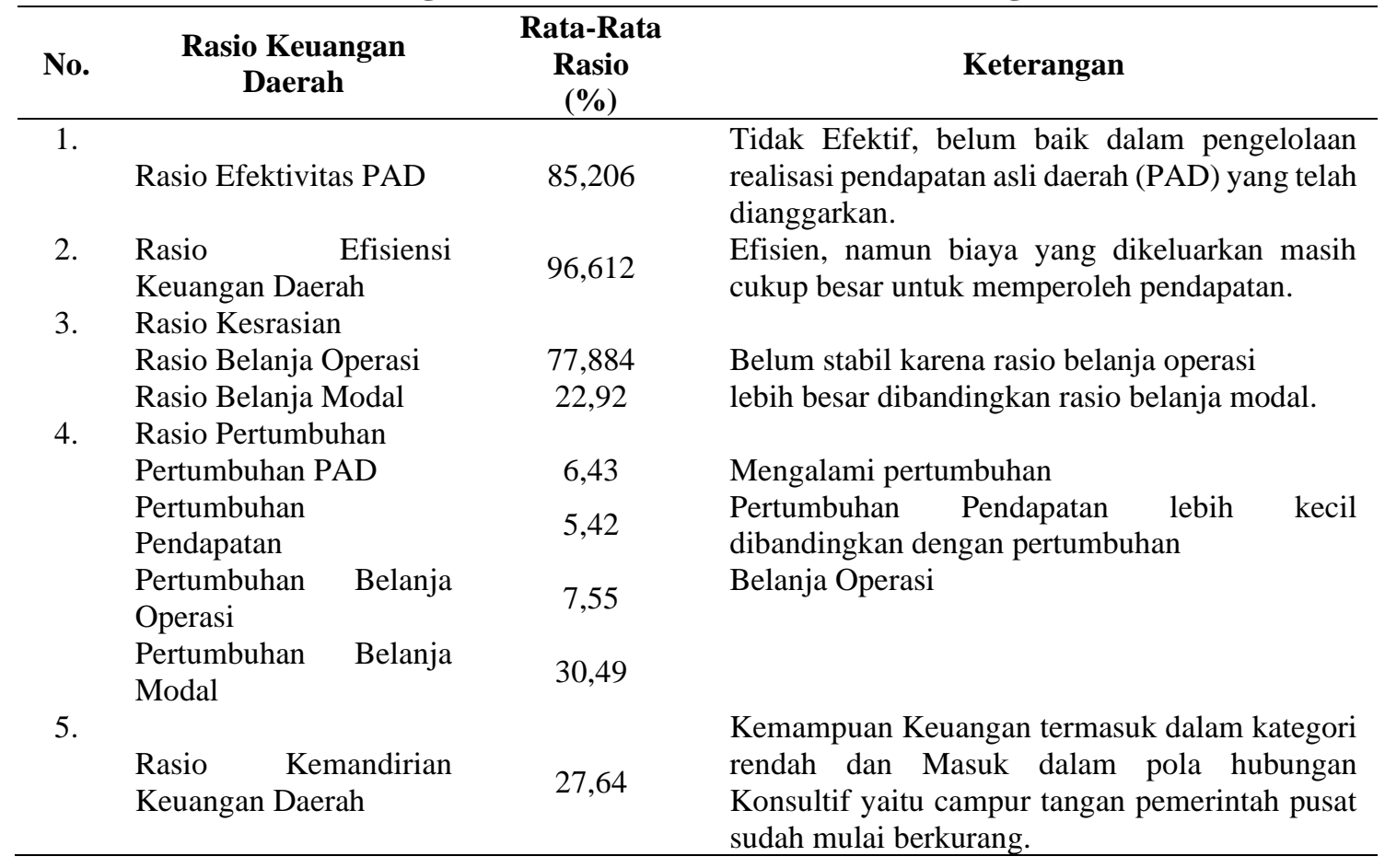

Sumber : data yang diolah

\section{Rasio Efektifitas PAD}

Rasio Efektifitas PAD Kota Salatiga berjalan tidak efektif karena rata- rata rasio efektifitas dibawah 100\%. Pemerintah Kota Salatiga dapat dikatakan belum baik dalam pengelolaan realisasi PAD yang telah dianggarkan. Untuk memperbaiki kondisi tersebut, Pemerintah Daerah harus mengoptimalkan penerimaan dari potensi pendapatan yang ada. Inisiatif dan kemauan Pemerintah Daerah sangat diperlukan dalam upaya peningkatan PAD. Pemerintah Daerah harus mencari jalan alternatif lain yang mungkin dapat mengatasi kekurangan pembiayaannya, dan untuk hal ini juga diperlukan kreatifitas dari 
aparat pelaksanaan keuangan daerah untuk mencari sumber-sumber pembiayaan baru melalui program kerjasama pembiayaan dengan pihak swasta dan juga program peningkatan PAD.

\section{Rasio Efisiensi Keuangan Daerah (REKD)}

Rata-rata Rasio Efisiensi Keuangan Pemerintah Kota Salatiga tergolong efisiesn, karena rata-rata rasionya sebesar 96,612\%, Meskipun rata-rata tingkat efisiensinya sudah efisien, biaya yang dikeluarkan Pemerintah Kota Salatiga masih cukup besar untuk memperoleh pendapatan. Dapat dikatakan kinerja Pemerintah Kota Salatiga masih tergolong belum dapat menekan jumlah belanja daerahnya. Untuk kedepannya diharapkan Pemerintah Kota Salatiga dapat meminimalisir jumlah belanja daerahnya dengan disesuaikan pendapatannya.

\section{Rasio Keserasian}

Rasio Keserasian Pemerintah Kota Salatiga Tahun 2014-2018 dapat diketahui bahwa rasio belanja operasi dan belanja modal belum stabil dari tahun ketahun. Dari hasil perhitungan Rasio Keserasian Pemerintah Kota Salatiga Tahun 2014-2018 menunjukkan bahwa sebagian besar dana yang dimiliki Pemerintah Kota Salatiga diutamakan untuk kebutuhan belanja operasi sehingga rasio belanja modal relatif kecil. Hal ini dapat dibuktikan dengan jumlah rata-rata rasio belanja operasi lebih besar dibandingkan dengan rata-rata rasio belanja modal. Besarnya alokasi dana untuk belanja operasi terutama dikarenakan besarnya jumlah belanja pegawai. Dengan ini dapat menunjukkan bahwa Pemerintah Kota Salatiga lebih condong pada pengeluaran-pengeluaran rutin untuk pemenuhan aktivitas pemerintahan. Dikarenakan belum adanya patokan yang pasti untuk belanja modal, sehingga Pemerintah Daerah masih terfokus pada pemenuhan belanja operasi yang mengakibatkan belanja modal kecil atau belum terpenuhi.

\section{Rasio Pertumbuhan}

Rasio Pertumbuhan Pemerintah Kota Salatiga mengalami pertumbuhan yang fluktuatif. Jika dilihat pertumbuhan pendapatan dari tahun ketahun selalu mengalami kenaikan maka dapat dikatakan rasio pertumbuhan pendapatan Pemerintah Kota Salatiga tumbuh secara positif. Upaya Pemerintah Kota Salatiga untuk meningkatkan pendapatan daerah bisa dikatakan berhasil walaupun sebagian besar pendapatanya bersumber dari pendapatan transfer atau bantuan dari pemerintah pusat. Untuk kedepanya untuk meningkatkan dan mengoptimalkan kinerja daerah maka Pemerintah Kota Salatiga harus selalu mengoptimalkan pendapatan daerahnya dari sektor PAD.

Rasio pertumbuhan belanja operasi dan belanja modal Pemerintah Kota Salatiga dapat dikatakan cukup baik, walaupun jumlah belanja operasinya masih lebih besar dibandingkan dengan belanja modalnya. Apabila Pemerintah Kota Salatiga mampu mengurangi belanja operasi dan dialokasikan untuk belanja modal maka bisa dikatakan Pemerintah Kota Salatiga menguatamakan pembangunan daerah.

\section{Rasio Kemandirian Keuangan Daerah (RKKD)}

Rasio Kemandirian Keuangan Daerah Pemerintah Kota Salatiga Tahun 2014-2018 dapat diketahui bahwa jumlah realisasi PAD Kota Salatiga tahun 2014-2018 mengalami kenaikan dan penurunan. 
Dalam perhitungan Rasio Kemandirian Keuangan Daerah diatas dapat dilihat bahwa tingkat kemandirian keuangan Kota Salatiga masih rendah dan pola hubungannya untuk tahun 2014, 2015, 2017, dan 2018 termasuk dalam pola hubungan konsultatif dan untuk tahun 2016 termasuk dalam pola instruktif dimana peranan Pemerintah Pusat lebih dominan daripada kemandirian Pemerintah Daerah. Rasio Kemandirian Keuangan Daerah Pemerintah Kota Salatiga dari tahun 2014 sampai 2018 rata-rata rasio kemandiriannya sebesar $27,64 \%$, dan masuk dalam pola hubungan konsultif yaitu campur tangan pemerintah pusat sudah mulai berkurang karena daerah dianggap sedikit lebih mampu melaksanakan otonomi daerah, ini dapat dilihat dari Rasio Kemandirian Keuangan Daerah masih tergolong dalam interval 25\%-50\%. Rasio Kemandirian yang masih rendah menggambarkan kemampuan keuangan daerah Kota Salatiga dalam membiayai pelaksanaan pemerintahan dan pembangunan daerah masih tergantung bantuan dari pemerintahpusat. Kemandirian Keuangan Pemerintah Kota Salatiga secara keseluruhan dapat dikatakan rendah, hal ini menggambarkan bahwa tingkat ketergantungan daerah terhadap sumber dana ekstern masih sangat tinggi. Daerah belum mampu mengoptimalkan PAD untuk membiayai pembangunan daerahnya. Kesadaran dan partisipasi masyarakat akan pembayaran pajak dan retribusi juga salah satu hal yang menyebabkan PAD yang dihasilkan Pemerintah Kota Salatiga sedikit dan belum bisa dapat diandalkan untuk membiayai pelaksanaan pemerintahan dan pembangunan. Selain itu, juga dikarenakan adanya perbedaan besarnya pinjaman serta bantuan dari pusat dan total pendapatan pada masing-masing daerah dan realisasi belanja pada masing-masing daerah. Untuk mengatasi hal tersebut, pemerintah daerah harus mampu mengoptimalkan penerimaan dari potensi pendapatannya yang telah ada. Inisiatif dan kemauan pemerintah daerah sangat diperlukan dalam upaya meningkatkan PAD, misalnya pendirian BUMD sektor potensial. Untuk kedepannya Pemerintah Daerah Kota Salatiga diharapkan selalu memaksimalkan potensi PAD yang ada, sehingga tidak selalu bergantung kepada bantuan dari pusat saja.

\section{PENUTUP}

Kinerja Keuangan Daerah Pemerintah Kota Salatiga jika dilihat dari Rasio Efektivitas PAD pada tahun 2014 s/d 2017 tergolong tidak efektif, karena rata-rata efektivitasnya dibawah $100 \%$, yakni sebesar 85,22\%. Kinerja Keuangan Daerah Pemerintah Kota Salatiga jika dilihat dari Rasio Efisiensi Keuangan Daerah Pemerintah Kota Salatiga pada tahun 2014-2018 dapat dikatakan Efisien, karena nilai rata-rata efisiensinya kurang dari $100 \%$ yaitu sebesar 96,61\%. Kinerja Keuangan Daerah Pemerintah Kota Salatiga jika dilihat dari Rasio Keserasian masih banyak mengalokasikan Belanja Operasi daripada Belanja Modalnya. rata-rata rasio sebesar 77,884\%., dan rata-rata Rasio Keserasian Belanja Modal yaitu sebesar 22,92\%. Rasio Pertumbuhan PAD mengalami pertumbuhan yang positif walaupun fluktuatif, rata-rata pertumbuhannya sebesar $6,43 \%$, sedikit lebih bagus bila dibandingkan dengan rata-rata pertumbuhan Pendapatannya yang rata-rata pertumbuhannya sebesar 5,42\%. Rasio Pertumbuhan Belanja Modal Kota Salatiga mengalami pertumbuhan secara positif, ratarata pertumbuhannya sebesar 30,49\% dibandingkan dengan Rasio Belanja operasi dengan rata-rata pertumbuhannya sebesar 7,55\%. Rasio Kemandirian Keuangan Daerah, tingkat kemandirian keuangan Kota Salatiga masih rendah termasuk dalam pola hubungan konsultatif. Rata-rata rasio kemandirian sebesar 27,64\%, dan masuk dalam pola 
hubungan konsultif yaitu campur tangan pemerintah pusat sudah mulai berkurang karena daerah dianggap sedikit lebih mampu melaksanakan otonomi daerah.

Pemerintah Kota Salatiga harus mampu meningkatkan dan memaksimalkan Pendapatan Asli Daerah. Sebenarnya potensi yang dimiliki Kota Salatiga mempunyai dampak yang besar bagi masyarakat sekitar. Potensi tersebut antara lain : di bidang pendidikan, kesehatan, pariwisata, kebudayaan, industri kreatif hingga perdagangan. Apabila pemerintah Kota Salatiga mampu memaksimalkan potensi tersebut, maka pajak yang merupakan pendapatan yang paling dominan dalam peningkatan Pendapatan Asli Daerah akan meningkat. Untuk mendukung peningkatan pajak dan retribusi, Pemerintah Kota Salatiga selalu melakukan pengawasan dan pengendalian secara benar dan berkelanjutan untuk menghindari terjadinya penyalahgunaan dalam pemerolehan Pendapatan Asli Daerah. Pemerintah Kota Salatiga juga seharusnya tidak selalu mengandalkan bantuan dari pemerintah pusat, agar kedepannya bisa tumbuh menjadi kota yang mandiri, mampu mengelola keuangannya dengan baik dan benar, serta kesejahteraan masyarakat lebih meningkat.

Hendaknya perlu melakukan penelitian yang lebih rinci lagi dalam menganalisa kinerja keuangan pemerintah daerah. Dengan menggunakan berbagai macam rasio yang lebih banyak dan bisa menggambarkan keadaan keuangan daerah yang sebenarnya. Selain itu, hendaknya penelitian untuk menambah lagi jangka waktu penelitian, tidak hanya 5 tahun saja. Penelitian juga disarankan untuk memperluas lingkup wilayah, tidak hanya mengambil dari 1 kabupaten saja tetapi lebih luas lagi.

\section{DAFTAR PUSTAKA}

Dewi, D. P. d. A., Priyo Hari. (2016). Analisis Kinerja Keuangan Pemerintah Daerah Melalui Pengelolaan Anggaran Pendapatan dan Belanja Daerah. Universitas Kristen Satya Wacana Salatiga, Retrieved from https://ris.uksw.edu/download/makalah/kode/M02358

Halim, A., \& Kusufi, M. S. (2007). Akuntansi sektor publik: Akuntansi keuangan daerah. Jakarta: Salemba Empat.

Halim, A., \& Kusufi, M. S. (2012). Akuntansi sektor publik. Jakarta: Salemba Empat.

Hamidi. (2005). Metode Kuantitatif: Aplikasi Praktis Pembuatan Proposal Dan Laporan Penelitian. Malang: UMM Press.

Harinaldi, D. I., \& Eng, M. (2005). Prinsip-prinsip statistik untuk teknik dan sains. Jakarta: Erlangga.

Mahmudi. (2016). Analisis Laporan Keuangan Pemerintah Daerah. Yogyakarta: UPP STIM YKPN.

Mahsun, M. (2012). Pengukuran kinerja sektor publik. Yogyakarta: BPFE.

Mardiasmo. (2002). Akuntansi Sektor Publik

Daerah, Manajemen Keuangan. Yogyakarta: Penerbit ANDI.

Pramono, J. (2014). Analisis rasio keuangan untuk menilai kinerja keuangan pemerintah daerah (Studi Kasus pada pemerintah Kota Surakarta). Among Makarti, 7(1).

Purwanto. (2007). Metodologi Penelitian Kuantitatif. Yogyakarta: Pustaka Pelajar.

Rahayu, A. D. E. (2017). Analisis Rasio Keuangan Daerah Untuk Menilai Kinerja Keuangan Daerah. (Skripsi), Universitas Nusantara PGRI, Kediri. 